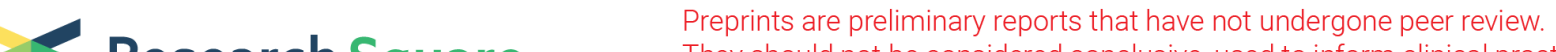 Research Square They should not be considered conclusive, used to inform clinical practice, or referenced by the media as validated information.
}

\section{Smartphone Apps to Support Laypersons in Bystander CPR Are of Ambivalent Benefit: a Randomized Controlled Trial Using Medical Simulation}

Camilla Metelmann ( $\square$ camilla.metelmann@uni-greifswald.de)

Universitatsmedizin Greifswald https://orcid.org/0000-0002-6145-9021

Bibiana Metelmann

University Medicine Greifswald: Universitatsmedizin Greifswald

Louisa Schuffert

University Medicine Greifswald: Universitatsmedizin Greifswald

Klaus Hahnenkamp

University Medicine Greifswald: Universitatsmedizin Greifswald

Peter Brinkrolf

University Medicine Greifswald: Universitatsmedizin Greifswald

Original research

Keywords: Resuscitation, cardiac arrest, teaching, health informatics, mHealth, smartphone

Posted Date: January 25th, 2021

DOI: https://doi.org/10.21203/rs.3.rs-152565/v1

License: (9) (i) This work is licensed under a Creative Commons Attribution 4.0 International License. Read Full License 


\section{Abstract}

Background: Bystander initiated resuscitation is essential. To encourage medical laypersons to perform resuscitation smartphone apps providing real-time guidance were invented. Are these apps a beneficial addition to traditional resuscitation training?

Methods: In a randomized controlled trial impact of app usage on quality of resuscitation in a standardised simulated cardiac arrest scenario was assessed. In a previous study the app "HELP Notfall" was selected for this purpose. Six weeks after a standardised resuscitation training pupils encountered a simulated cardiac arrest (i) without app (control group); (ii) with facultative app usage (facultative group); (iii) with mandatory app usage (mandatory group).

Results: 200 pupils attended this study with 74 pupils (37\%) in control group, 65 (32,5\%) in facultative group and $61(30,5 \%)$ in mandatory group. Participants using the app in mandatory group had a significantly higher percentage of chest compressions with the correct compression rate $(65.4 \%$ vs. $43.8 \%$; $p<0.01)$ and with correct compression depth $(47.6 \%$ vs. $24.4 \% ; p=0.001)$ than pupils of the control group. Participants of the mandatory group had a significant delay compared with control group regarding time until check for breathing ( 23 sec. vs. 12 sec., $p<0.001$ ), call for help (35 sec. vs. 20 sec., $p<0.001$ ) and first compression (68 sec. vs. $29 \mathrm{sec} ., \mathrm{p}<0.001$ ). Hands-off-time during compression tended to be shorter in mandatory group ( $0.5 \mathrm{sec}$.) compared with control group $(1.5 \mathrm{sec}),.(p=0.36)$.

Conclusions: Smartphone apps offering real-time guidance in resuscitation are of mixed benefits. An improved quality of chest compression is countered by a delayed start of chest compressions. Both aspects have to be considered before recommending smartphone apps to support laypersons in bystander resuscitation as an addition to traditional hands-on training.

\section{Introduction}

Treatment of out-of-hospital cardiac arrest (OHCA) needs to start as early as possible [1]. If cardiopulmonary resuscitation (CPR) is initiated by a bystander, the likelihood of survival can be substantially increased [2-4]. Even bystanders, who are medical laypersons, enhance the prospect of survival of OHCA with favourable neurological outcome [5, 6]. Hence, the European Resuscitation Counsel (ERC) as well as the American Heart Association (AHA) promote bystander CPR [7, 8]. However, although most OHCA are witnessed, rates of bystander CPR are low, with high variance between European countries [9-12]. One of the impediments, why medical laypersons do not start CPR, is limited knowledge [13-15]. Therefore, a multitude of different teaching concepts has been successfully implemented resulting in higher rates of bystander CPR [16-19]. With the increasing spread of smartphones, one approach is to use smartphone applications for teaching CPR skills. The ERC guidelines 2015 encourage use of mobile technologies in CPR[20] and AHA calls for further studies analysing mobile devices to facilitate CPR [21]. Apps suitable for individual and group teaching were shown to sufficiently increase CPR knowledge [2224]. 
However, CPR training reaches not all parts of the community, resulting in lower surviving rates [25]. Hence, additionally to smartphone apps teaching CPR in advance, another kind of apps was developed, which offer ubiquitous, real time guidance to medical laypersons encountering OHCA. Those apps focus on stepby-step instructions without providing background information and, thus, differ innately from other teaching apps. Exemplarily, a Japanese smartphone app providing real-time explanations on how to perform CPR let to a higher proportion of chest compressions in a simulation study with medical laypersons [26]. Yet, out of all apps providing real-time guidance, only few are in concordance with the resuscitation guidelines and user friendly $[27,28]$.

High-quality smartphone apps providing real-time guidance might be a beneficial addition to traditional CPR training by providing higher knowledge retention and serving as a reminder.

\section{Methods}

\section{Aim, design, setting of the study}

This study evaluates, whether the quality of bystander cardiopulmonary resuscitation by medical laypersons is higher, if bystanders are supported by a smartphone app providing real-time guidance.

The smartphone app used in this study was selected in a three-step-approach. In this process consisting of (i) a systematic review of apps guiding a medical layperson through a resuscitation situation, (ii) an adherence-testing to medical guidelines and (iii) a usability evaluation, the smartphone app "HELP Notfall" by Schweizerische Herzstiftung version 1.0 was assessed as "best suitable". The detailed results of this selection process have been published before [28].

In this study the smartphone app was evaluated using medical simulation in a randomized controlled trial. To analyse impact of app usage on quality of resuscitation, a case-control-design with 3 different groups was chosen, as depicted in Fig. 1. While the control group was not allowed to use a smartphone in a standardised simulated cardiac arrest scenario; the facultative group was allowed to use the app, if they thought it to be beneficial; whereas members of the mandatory group had to use the app. All three study groups received a standardised 30 minutes seminar on bystander CPR in groups of maximally 25 participants. Seminars were based on the ERC guidelines 2015 and one-person hands-only-CPR was taught [29]. Topics covered were detecting cardiac arrest, calling for help and features of high quality chest compression. All seminars were held by the same lecturer (LS), who is a senior medical student and experienced paramedic. In seminars for the control group the app was not mentioned. Participants in the facultative group were encouraged to download the app "HELP Notfall" after the seminar to familiarize themselves with it. Whereas participants in the mandatory group were introduced to the app and operation of the app was demonstrated and practised. In all groups the seminar was followed by individual hands-ontraining using manikins, which provide real-time feedback. During this one-to-one training, each participant received individual feedback to practise the algorithm and to increase quality of chest compression. Pupils in mandatory group used the app during training. While members of control group were provided with a fact 
sheet summarizing the seminar, members of facultative and mandatory group were encouraged to download the app "HELP Notfall” on their personal smartphone.

With a fixed time interval of six weeks after seminar and hands-on-training, resuscitation skills were assessed. In a standardised scenario (collapsed person in a park) all participants individually encountered and detected and treated a simulated cardiac arrest. Quality of resuscitation was assessed using simulation manikin Brayden ${ }^{\circledR}$ (Innosonian ${ }^{\circledR}$, South Korea). The Brayden Pro scoring algorithm records and presents information on chest compression rate, depth, release, fraction and hand position. Data collection by manikin and software was used to ensure comprehensive data capture for each participant. During examination two study group members were present. One study group member operated the tablet computer assessing Brayden Pro scoring algorithm and measured the time. The other examiner evaluated the quality of resuscitation with aid of a checklist regarding detection of unconsciousness, assessment of breathing and body position during chest compression on a score chart (translated version provided as ESupplement). While members of control group entered the scenario without a smartphone; members of facultative group could use the app "HELP Notfall" on a voluntary basis; whereas members of mandatory group were told to use the app. For participants, who had either no smartphone, forgotten to download the app, or had problems operating the app on their smartphone, a smartphone (iPhone 7) was provided.

\section{Participants' characteristics}

All participants were pupils in class 8 to 11 from different schools with higher German education. School pupils were chosen as study participants, because they have comparable general knowledge, comparable knowledge regarding medical emergencies and resuscitation and comparable physical fitness. Additionally, school kids use internet and apps as their main source of information and first choice in cases of questions $[30,31]$, hence are bound to be more likely to use a smartphone app. This study population includes both persons interested and not interested in CPR; in contrast to studies with volunteers, which might be biased by higher motivation [32]. Randomisation into the three groups was done per school to minimize contact between different study groups. The aim was to reduce the risk of pupils in control group downloading the app, because they were told about the app in the schoolyard by pupils of the other two groups. The study was carried out from October 2017 to July 2018.

\section{Statistical Analysis}

Based on our power-analysis and a study done by Paal and colleagues, we recruited school classes to include 60 pupils per group [33]. Statistical processing of the data was carried out using IBM SPSS Statistics, version 25.0 (IBM Corporation, Armonk, New York, USA) and Microsoft Excel 2010 (Microsoft Corporation, Redmond, Washington, USA). We assessed normal distribution by Shapiro-Wilk-Test; median and interquartile range were calculated. In case of normal distribution, t-test was used to assess significance levels. In cases without normal distribution, Mann-Whitney-U-Test was used.

\section{Results}


200 pupils attended this study with 74 pupils (37\%) in control group, 65 pupils $(32,5 \%)$ in facultative group and 61 pupils $(30,5 \%)$ in mandatory group. Characteristics of study participants are depicted in Table 1. There was no significant difference regarding gender, pre-existing first aid knowledge and previous exposure to emergency situations. Yet, there was a significant difference regarding age with pupils in facultative group being youngest (mean age 14 years) and pupils in mandatory group being oldest (mean age 15 years). 
Table 1

Characteristics of study participants

\begin{tabular}{|c|c|c|c|c|c|c|c|}
\hline & $\begin{array}{l}\text { Total } \\
(n, \%)\end{array}$ & $\begin{array}{l}\text { Control } \\
\text { group } \\
(n, \%)\end{array}$ & $\begin{array}{l}\text { Facultative } \\
\text { group } \\
(n, \%)\end{array}$ & $\begin{array}{l}\text { Mandatory } \\
\text { group } \\
(n, \%)\end{array}$ & $\begin{array}{l}\text { Control vs. } \\
\text { facultative } \\
\text { group }\end{array}$ & $\begin{array}{l}\text { Control vs. } \\
\text { mandatory } \\
\text { group }\end{array}$ & $\begin{array}{l}\text { Facultative } \\
\text { vs. } \\
\text { mandatory } \\
\text { group }\end{array}$ \\
\hline $\begin{array}{l}\text { Number of } \\
\text { participants }\end{array}$ & 200 & $\begin{array}{l}74 \\
(37.0)\end{array}$ & 65 (32.5) & $61(30.5)$ & & & \\
\hline Gender & 197 & 71 & 65 & 61 & $p=0.34$ & $p=0.29$ & $p=0.77$ \\
\hline Male & $\begin{array}{l}95 \\
(48.2)\end{array}$ & $\begin{array}{l}37 \\
(52.1)\end{array}$ & 31 (47.7) & $27(44.3)$ & & & \\
\hline Female & $\begin{array}{l}102 \\
(51.8)\end{array}$ & $\begin{array}{l}34 \\
(47.9)\end{array}$ & $34(52.3)$ & $34(55.7)$ & & & \\
\hline Age & 196 & 71 & 64 & 61 & $p=0.003$ & $p=0.001$ & $p<.0001$ \\
\hline 13 & $\begin{array}{l}37 \\
(18.9)\end{array}$ & $\begin{array}{l}14 \\
(19.7)\end{array}$ & $23(35.9)$ & 0 & & & \\
\hline 14 & $\begin{array}{l}53 \\
(27.0)\end{array}$ & $\begin{array}{l}21 \\
(29.6)\end{array}$ & $24(37.5)$ & $8(13.1)$ & & & \\
\hline 15 & $\begin{array}{l}57 \\
(29.1)\end{array}$ & $\begin{array}{l}16 \\
(22.5)\end{array}$ & $10(15.6)$ & $31(50.8)$ & & & \\
\hline 16 & $\begin{array}{l}32 \\
(16.3)\end{array}$ & $\begin{array}{l}10 \\
(14.1)\end{array}$ & $7(10.9)$ & $15(24.6)$ & & & \\
\hline 17 & $\begin{array}{l}17 \\
(8.7)\end{array}$ & $\begin{array}{l}10 \\
(14.1)\end{array}$ & 0 & $7(11.5)$ & & & \\
\hline $\begin{array}{l}\text { Preexisting } \\
\text { first aid } \\
\text { knowledge* }\end{array}$ & 192 & 77 & 63 & 52 & $p=0.17$ & $p=0.91$ & $p=0.14$ \\
\hline None & $\begin{array}{l}71 \\
(37.0)\end{array}$ & $\begin{array}{l}29 \\
(37.7)\end{array}$ & 19 (30.1) & $23(44.3)$ & & & \\
\hline $\begin{array}{l}\text { First Aid } \\
\text { Course }\end{array}$ & $\begin{array}{l}105 \\
(54.7)\end{array}$ & $\begin{array}{l}37 \\
(48.1)\end{array}$ & $42(66.7)$ & $26(50.0)$ & & & \\
\hline $\begin{array}{l}\text { Member of } \\
\text { volunteer } \\
\text { fire brigade }\end{array}$ & $\begin{array}{l}5 \\
(2.6)\end{array}$ & $4(5.2)$ & $1(1.6)$ & 0 & & & \\
\hline $\begin{array}{l}\text { School } \\
\text { paramedic }\end{array}$ & $\begin{array}{l}4 \\
(2.1)\end{array}$ & $3(3.8)$ & 0 & $1(1.9)$ & & & \\
\hline Other & $\begin{array}{l}7 \\
(3.6)\end{array}$ & $4(5.2)$ & $1(1.6)$ & $2(3.8)$ & & & \\
\hline
\end{tabular}




\begin{tabular}{|c|c|c|c|c|c|c|c|}
\hline & $\begin{array}{l}\text { Total } \\
(n, \%)\end{array}$ & $\begin{array}{l}\text { Control } \\
\text { group } \\
(n, \%)\end{array}$ & $\begin{array}{l}\text { Facultative } \\
\text { group } \\
(n, \%)\end{array}$ & $\begin{array}{l}\text { Mandatory } \\
\text { group } \\
(n, \%)\end{array}$ & $\begin{array}{l}\text { Control vs. } \\
\text { facultative } \\
\text { group }\end{array}$ & $\begin{array}{l}\text { Control vs. } \\
\text { mandatory } \\
\text { group }\end{array}$ & $\begin{array}{l}\text { Facultative } \\
\text { vs. } \\
\text { mandatory } \\
\text { group }\end{array}$ \\
\hline $\begin{array}{l}\text { Have you } \\
\text { been in an } \\
\text { emergency } \\
\text { situation } \\
\text { before? }\end{array}$ & 196 & 74 & 61 & 61 & $p=0.30$ & $p=0.51$ & $p=0.71$ \\
\hline Yes & $\begin{array}{l}12 \\
(6.1)\end{array}$ & $3(4.1)$ & $5(8.2)$ & $4(6.6)$ & & & \\
\hline No & $\begin{array}{l}184 \\
(93.9)\end{array}$ & $\begin{array}{l}71 \\
(95.9)\end{array}$ & 56 (91.8) & $57(93.4)$ & & & \\
\hline
\end{tabular}

To ascertain cardiac arrest, pupils had to assess consciousness, airway obstruction and breathing. As depicted in Table 2, there were no significant differences between pupils using the app and pupils without app. 
Table 2

Assessment of consciousness, airway obstruction and breathing

\begin{tabular}{|c|c|c|c|c|c|c|}
\hline & $\begin{array}{l}\text { Control } \\
\text { group } \\
(n, \%)\end{array}$ & $\begin{array}{l}\text { Facultative } \\
\text { group } \\
(n, \%)\end{array}$ & $\begin{array}{l}\text { Mandatory } \\
\text { group } \\
(n, \%)\end{array}$ & $\begin{array}{l}\text { Control vs. } \\
\text { facultative } \\
\text { group }\end{array}$ & $\begin{array}{l}\text { Control vs. } \\
\text { mandatory } \\
\text { group }\end{array}$ & $\begin{array}{l}\text { Facultative } \\
\text { vs. } \\
\text { mandatory } \\
\text { group }\end{array}$ \\
\hline $\begin{array}{l}\text { Assessment of } \\
\text { consciousness }\end{array}$ & $n=74$ & $n=64$ & $n=60$ & $p=0.26$ & $p=0.51$ & $p=0.85$ \\
\hline Not checked & $\begin{array}{l}5 \\
(6.8 \%)\end{array}$ & $2(3.1 \%)$ & $3(5.0 \%)$ & & & \\
\hline $\begin{array}{l}\text { Spoke to or } \\
\text { touched person }\end{array}$ & $\begin{array}{l}2 \\
(2.7 \%)\end{array}$ & $5(7.8 \%)$ & $4(6.7 \%)$ & & & \\
\hline $\begin{array}{l}\text { Spoke to and } \\
\text { touched person }\end{array}$ & $\begin{array}{l}67 \\
(90.5 \%)\end{array}$ & 57 (89.1\%) & $53(88.3 \%)$ & & & \\
\hline $\begin{array}{l}\text { Assessment of } \\
\text { airway } \\
\text { obstruction }\end{array}$ & $n=74$ & $n=63^{*}$ & $n=60$ & $p=0.42$ & $p=0.38$ & $p=0.78$ \\
\hline Not checked & $\begin{array}{l}24 \\
(32.4 \%)\end{array}$ & 19 (30.2\%) & $15(25.0 \%)$ & & & \\
\hline $\begin{array}{l}\text { Checked, but } \\
\text { not correctly }\end{array}$ & $\begin{array}{l}9 \\
(12.2 \%)\end{array}$ & $13(20.6 \%)$ & $12(20.0 \%)$ & & & \\
\hline $\begin{array}{l}\text { Correctly } \\
\text { checked }\end{array}$ & $\begin{array}{l}41 \\
(55.4 \%)\end{array}$ & $31(49.2 \%)$ & $33(55.0 \%)$ & & & \\
\hline $\begin{array}{l}\text { Assessment of } \\
\text { breathing }\end{array}$ & $n=74$ & $n=64$ & $n=60$ & $p=0.29$ & $p=0.03$ & $p=0.05$ \\
\hline Not checked & $\begin{array}{l}7 \\
(9.5 \%)\end{array}$ & $4(6.2 \%)$ & 0 & & & \\
\hline $\begin{array}{l}1 \text { out of look, } \\
\text { listen, feel }\end{array}$ & $\begin{array}{l}5 \\
(6.8 \%)\end{array}$ & $5(7.8 \%)$ & $10(16.7 \%)$ & & & \\
\hline $\begin{array}{l}2 \text { out of look, } \\
\text { listen, feel }\end{array}$ & $\begin{array}{l}14 \\
(18.8 \%)\end{array}$ & 20 (31.3\%) & $12(20.0 \%)$ & & & \\
\hline $\begin{array}{l}3 \text { out of look, } \\
\text { listen, feel }\end{array}$ & $\begin{array}{l}48 \\
(64.9 \%)\end{array}$ & 35 (54.7\%) & 38 (63.3\%) & & & \\
\hline
\end{tabular}

Out of 200 pupils 198 (99\%) performed chest compressions. As shown in Table 3 pupils using the app in mandatory group had a significantly higher percentage of chest compressions with the correct compression rate of $100-120 \mathrm{bpm}$ compared to pupils in control group $(p=0.002)$. Furthermore, pupils in the mandatory group achieved significantly more often a recommended compression depth of $5-6 \mathrm{~cm}$ 
than pupils in control or facultative group ( $p=0.001, p=0.008$ resp.). There were no significant differences between the three groups regarding release of chest compression and hand positioning.

Table 3

Quality of chest compression

\begin{tabular}{|c|c|c|c|c|c|c|}
\hline & $\begin{array}{l}\text { Control } \\
\text { group }\end{array}$ & $\begin{array}{l}\text { Facultative } \\
\text { group }\end{array}$ & $\begin{array}{l}\text { Mandatory } \\
\text { group }\end{array}$ & $\begin{array}{l}\text { Control vs. } \\
\text { facultative } \\
\text { group }\end{array}$ & $\begin{array}{l}\text { Control vs. } \\
\text { mandatory } \\
\text { group }\end{array}$ & $\begin{array}{l}\text { Facultative } \\
\text { vs. } \\
\text { mandatory } \\
\text { group }\end{array}$ \\
\hline $\begin{array}{l}\text { Correct compression } \\
\text { rate }\left[100-120 / \mathrm{min}^{-}\right. \\
\left.{ }^{1}\right](\%)\end{array}$ & & & & $p=0.66$ & $p=0.002$ & $p=0.66$ \\
\hline $\begin{array}{l}\text { mean (standard } \\
\text { deviation) }\end{array}$ & $\begin{array}{l}43.8 \\
( \pm 36.8)\end{array}$ & $\begin{array}{l}39.2 \\
( \pm 34.8)\end{array}$ & $\begin{array}{l}65.4 \\
( \pm 32.7)\end{array}$ & & & \\
\hline Median & 42 & 32 & 81 & & & \\
\hline $\begin{array}{l}\text { Correct compression } \\
\text { depth }[5-6 \mathrm{~cm}](\%)\end{array}$ & & & & $p=0.72$ & $p=0.001$ & $p=0.008$ \\
\hline $\begin{array}{l}\text { mean (standard } \\
\text { deviation) }\end{array}$ & $\begin{array}{l}24.4 \\
( \pm 30.4)\end{array}$ & $\begin{array}{l}30.1 \\
( \pm 35.2)\end{array}$ & $\begin{array}{l}47.6 \\
( \pm 37.3)\end{array}$ & & & \\
\hline median & 10 & 7.5 & 51.5 & & & \\
\hline $\begin{array}{l}\text { Correct release of } \\
\text { compression (\%) }\end{array}$ & & & & $p=0.04$ & $p=0.49$ & $p=0.24$ \\
\hline $\begin{array}{l}\text { mean (standard } \\
\text { deviation) }\end{array}$ & $\begin{array}{l}89.7 \\
( \pm 22.6)\end{array}$ & $\begin{array}{l}81.7 \\
( \pm 30.9)\end{array}$ & $\begin{array}{l}87.8 \\
( \pm 23.8)\end{array}$ & & & \\
\hline Median & 100 & 98 & 100 & & & \\
\hline $\begin{array}{l}\text { Correct hand } \\
\text { position (\%) }\end{array}$ & & & & $p=0.77$ & $p=0.05$ & $p=0.08$ \\
\hline $\begin{array}{l}\text { mean (standard } \\
\text { deviation) }\end{array}$ & $\begin{array}{l}76.8 \\
( \pm 28.3)\end{array}$ & $\begin{array}{l}77.6 \\
( \pm 30.9)\end{array}$ & $\begin{array}{l}86.4 \\
( \pm 19.0)\end{array}$ & & & \\
\hline Median & 90 & 95 & 97 & & & \\
\hline
\end{tabular}

A high quality CPR requires optimal body and arm positioning during chest compression. Pupils of the mandatory group were guided by the app and had a significantly better body position than pupils without app guidance in control group ( $p=0.002)$, (see Table 4). There were no significant differences detectable regarding correct arm posture. 
Table 4

Positioning of first aider during chest compressions

\begin{tabular}{|lllllll|}
\hline & $\begin{array}{l}\text { Control } \\
\text { group } \\
(n, \%)\end{array}$ & $\begin{array}{l}\text { Facultative } \\
\text { group } \\
(n, \%)\end{array}$ & $\begin{array}{l}\text { Mandatory } \\
\text { group } \\
(n, \%)\end{array}$ & $\begin{array}{l}\text { Control vs. } \\
\text { facultative } \\
\text { group }\end{array}$ & $\begin{array}{l}\text { Control vs. } \\
\text { mandatory } \\
\text { group }\end{array}$ & $\begin{array}{l}\text { Facultative vs. } \\
\text { mandatory } \\
\text { group }\end{array}$ \\
\hline $\begin{array}{l}\text { Body } \\
\text { position }\end{array}$ & $\mathrm{n}=74$ & $\mathrm{n}=64$ & $\mathrm{n}=60$ & $\mathrm{p}=0.05$ & $\mathrm{p}=0.002$ & $\mathrm{p}=0.09$ \\
\hline Correct & $\begin{array}{l}63 \\
(85.1)\end{array}$ & $61(95.4)$ & $60(100)$ & & & \\
\hline $\begin{array}{l}\text { Arm } \\
\text { posture }\end{array}$ & $\mathrm{n}=74$ & $\mathrm{n}=64$ & $\mathrm{n}=60$ & $\mathrm{p}=0.31$ & $\mathrm{p}=0.49$ & $\mathrm{p}=0.76$ \\
\hline Correct & $\begin{array}{l}72 \\
(97.3)\end{array}$ & $60(93.7)$ & $57(95.0)$ & & & \\
\hline
\end{tabular}

To access further parameters of high quality CPR, times were taken during the simulation. The measured time intervals are shown in Fig. 2 and E-Table 1. In groups using the app (facultative and mandatory group) a significant delay until check for breathing, call for help and first compression was detectable (in each case $p<0.001)$. Assessment of breathing was done in similar time spans in all groups.

Hands-off-time during compression differed: while pupils not using the app (control group) had a mean pause during compression of 1.5 seconds, pupils with mandatory use of app had a mean pause of 0.5 seconds during compression, which was not statistically significant $(p=0.36)$. Pupils with facultative app usage had a mean interruption during compression of 11.0 seconds. The total hands-off-time (combination of time until first compression and pause during compression) was significantly longer, when using the app $(p=<0.001)$.

\section{Discussion}

Using smartphone app-based real-time instruction in resuscitation is thought to be beneficial, because mobile phones are often close at hand and might reduce fear of making mistakes during CPR[34]. As our results illustrate, smartphone guidance shows mixed benefits.

For detection and treatment of persons with suspected cardiac arrest an easy to follow algorithm was developed for medical laypersons[7]. This algorithm involves check of consciousness, check for breathing, call for help and start of chest compressions and was taught in our study. During the simulated scenario most pupils adhered to this algorithm, regardless of whether the app was used or not. While check of consciousness was done correctly by most pupils, check for airway obstructions and assessment of normal breathing were a higher challenge. Even pupils, who received detailed instruction by the app, had difficulties performing this task. In a study done by Choa, participants, who were shown videos using animated motion capture technique on a smartphone app, performed better airway management (head tilt- 
chin lift manoeuvre and checking for breathing) in comparison to participants receiving audio-guidance only [35].

High quality chest compression is essential for survival [36]. A chest compression rate of 100-120 compressions per minute was shown to be the optimal frequency of thoracic compression [37, 38]. Instructions issued by the app lead to a significantly higher amount of chest compressions within the recommended pace. This might be accountable to the metronome, similar to findings in a study by Paal [33].

High quality CPR further includes a chest compression depth of 5-6 cm [38]. In our study, pupils using the app achieved significantly more often the recommended compression depth. The results regarding improved chest compression rate and depth are in concordance with a study by Merchant et al, who tested the benefit of CPR-instructions by voicemail using a flip-design cell telephone [39]. Concordantly, a study done by Choa et al. showed better chest compression quality when using an app showing video clips [35].

Alongside a deep chest compression, a total release of compression is also necessary[29]. In our study no differences between pupils with and without app use were seen. This is probably due to the fact, that the app did not address release of chest compression. Also, no significant differences were seen regarding hand position on the chest.

To achieve adequate chest compression depth and rate, it is advisable to kneel directly beside the victim and to press with both arms stretched. While app guidance led to a significantly better body position, no significant differences regarding correct arm posture was detectable. Nearly all pupils used correct body and arm positioning, probably because it was demonstrated in the CPR training six weeks in advance. Correct body and arm position can be learnt best with hands-on-training. Hence, smartphone guidance in real-time should be considered as an additional tool to support traditional hands-on CPR training, because important psychomotor skills can be better taught in direct training with manikins [35].

In cardiac arrest it is essential to start resuscitation as soon as possible $[8,29]$. Numerous studies could show a benefit for early start of chest compressions by bystanders [40, 41]. Hence, it is of paramount importance that real-time guidance by smartphones does not lead to a substantial time delay[33]. Yet, in our study pupils, who examined the manikin for cardiac arrest with support by the smartphone app, took longer time to start and complete check for breathing, more time to call for help and more time until first chest compression. This prolonged time until first compression was also found in other studies evaluating real-time guidance through mobile phones or smartphones $[26,33,39]$. In studies comparing app or videodemonstrated instructions with audio-only instructions (as in telephone-CPR), time until first chest compression was found to be shorter with app-/ video-based instructions [42, 43].

When scrutinising these findings, several aspects have to be considered. All pupils in our study received a CPR training six weeks ahead of this examination. Different results may be found with laypersons, whose training was years ago or who had no previous training. Medical laypersons without CPR training are often overwhelmed by the situation and are afraid of doing something wrong and might prefer doing nothing at all [44]. Hence, smartphone guidance may prompt them to assess consciousness and breathing. 
Additionally, it helps bystanders with limited CPR knowledge to remember all steps. Furthermore, in our study the time delay ascribable to the app accounts for approximately one minute. This is a relatively small loss of time compared to a situation, in which no bystander CPR is initiated and first chest compression is done by ambulance crew. Hence, in an app leading to a higher amount of high quality bystander CPR, one could argue, that a loss of time of approximately one minute might be acceptable. Additionally, pupils using the app tended to have fewer and shorter pauses during chest compressions. In situations, in which the ambulance takes 10 minutes or longer to reach the emergency site, the initial time delay might be mitigated by a shorter overall hands-off-time.

\section{Limitations}

This study is a simulation study with manikins, thus, generalisability to real-life scenarios is limited. Resuscitation was performed with one-person hands-only CPR, which might be different in real-life scenarios. This study was done with pupils. Because of their young age this reduces the transferability to other bystanders. Pupils in mandatory group were slightly older than pupils in the other groups, which could lead to a greater body strength resulting in deeper chest compressions [45]. However, heights and weights differences in pupils of 14-15 years are not as pronounced as in younger years [45].

Randomisation into the three groups was done on school level to reduce communication between different study groups. However, it bears the risk of bias by different educational strategies of different schools. We tried to diminish this bias by providing every pupil with a standardised CPR-training.

The timespan between training and examination was six weeks. Other results may have been observed after a different time interval. Pupils in the mandatory group, were trained how to operate the app. Outside study environment people often download apps without familiarizing with it [46]. Thus, they might not know how to operate the app in case of witnessing cardiac arrest and are expected to have longer time delays before starting CPR.

During simulation the duration of chest compressions was stopped after two minutes to allow standardisation, similar to other studies[26, 47]. In real emergencies, CPR by bystanders is often required for a longer time-interval. A longer timespan might pronounce or mitigate the differences in quality of chest compressions.

\section{Future outlook}

To allow qualified recommendation regarding smartphone app- based real-time guidance for medical laypersons in resuscitation, studies evaluating the benefits and drawbacks in real cardiac arrests are needed. The future goal is to analyse impact on return of spontaneous circulation and quality of life.

\section{Conclusions}

Before recommending apps offering real-time guidance in resuscitation to medical laypersons, it is essential to analyse potential risks and benefits. This study examined in case-control-design indicators of 
high quality CPR in pupils detecting and treating a simulated cardiac arrest with or without help of a smartphone app offering real-time guidance. While some aspects of high quality CPR were improved in the group using the smartphone app (correct chest compression rate and depth, correct body positioning), other aspects still remain a challenge to medical laypersons (assessment of airway obstruction and normal breathing). Additionally, app usage was associated with a delayed start of chest compressions. Hence, such smartphone apps are of mixed benefits. Besides an improved quality of chest compression an increased hands-off-time has to be considered as well. We tentatively recommend using smartphone apps to support laypersons in bystander CPR as an addition to hands-on CPR training.

\section{List Of Abbreviations}

AHA - American Heart Association

CPR - cardiopulmonary resuscitation

ERC - European Resuscitation Counsel

OHCA - out-of-hospital cardiac arrest

\section{Declarations}

Ethics approval and consent to participate: The study was approved by the Institutional Review Board of Universitaetsmedizin Greifswald with the case number BB 055/17. All participants and their parents or legal guardians consented orally and written to participation in this study.

Consent for publication: Not applicable

Availability of data and materials: The datasets generated and analysed during the current study are available from the corresponding author on reasonable request.

Competing interests: The authors declare that they have no competing interests.

Funding: This work was funded by Klinik fuer Anaesthesiologie, Universitaetsmedizin Greifswald.

Authors' contributions: All authors were involved in designing the study. CM, BM and LS organised and conducted training and assessment. Analyses were done by CM, BM, LS and PB. The manuscript was written by $\mathrm{CM}$ and $\mathrm{BM}$. All authors contributed to the manuscript and approved the final version.

Acknowledgements: The authors would like to thank the teachers and pupils, who enabled this study and the members of ForschungsAG Notfallmedizin Universitaetsmedizin Greifswald for their continuous support. Additionally, the authors would like to thank Marcus Vollmer for his excellent advices regarding statistical analyses.

\section{References}


1. Sasson C, Rogers MAM, Dahl J, Kellermann AL. Predictors of survival from out-of-hospital cardiac arrest: A systematic review and meta-analysis. Circ Cardiovasc Qual Outcomes. 2010;3:63-81. doi:10.1161/CIRCOUTCOMES.109.889576.

2. Malta Hansen C, Kragholm K, Pearson DA, Tyson C, Monk L, Myers B, et al. Association of Bystander and First-Responder Intervention With Survival After Out-of-Hospital Cardiac Arrest in North Carolina, 2010-2013. JAMA. 2015;314:255-64. doi:10.1001/jama.2015.7938.

3. Riddersholm S, Kragholm K, Mortensen RN, Pape M, Hansen CM, Lippert FK, et al. Association of bystander interventions and hospital length of stay and admission to intensive care unit in out-ofhospital cardiac arrest survivors. Resuscitation. 2017;119:99-106. doi:10.1016/j.resuscitation.2017.07.014.

4. Fordyce CB. Reduced critical care utilization: Another victory for effective bystander interventions in cardiac arrest. Resuscitation. 2017;119:A4-A5. doi:10.1016/j.resuscitation.2017.08.009.

5. Hasselqvist-Ax I, Riva G, Herlitz J, Rosenqvist M, Hollenberg J, Nordberg P, et al. Early cardiopulmonary resuscitation in out-of-hospital cardiac arrest. N Engl J Med. 2015;372:2307-15. doi:10.1056/NEJMoa1405796.

6. Park GJ, Song KJ, Shin SD, Lee KW, Ahn KO, Lee EJ, et al. Timely bystander CPR improves outcomes despite longer EMS times. Am J Emerg Med. 2017;35:1049-55. doi:10.1016/j.ajem.2017.02.033.

7. Monsieurs KG, Nolan JP, Bossaert LL, Greif R, Maconochie IK, Nikolaou NI, et al. European Resuscitation Council Guidelines for Resuscitation 2015: Section 1. Executive summary. Resuscitation. 2015;95:1-80. doi:10.1016/j.resuscitation.2015.07.038.

8. Kleinman ME, Goldberger ZD, Rea T, Swor RA, Bobrow BJ, Brennan EE, et al. 2017 American Heart Association Focused Update on Adult Basic Life Support and Cardiopulmonary Resuscitation Quality: An Update to the American Heart Association Guidelines for Cardio pulmonary Resuscitation and Emergency Cardiovascular Care. Circulation 2017. doi:10.1161/CIR.0000000000000539.

9. Gräsner J-T, Böttiger BW, Bossaert L. EuReCa ONE - ONE month - ONE Europe - ONE goal. Resuscitation. 2014;85:1307-8. doi:10.1016/j.resuscitation.2014.08.001.

10. Bosson N, Fang A, Kaji AH, Gausche-Hill M, French WJ, Shavelle D, et al. Racial and ethnic differences in outcomes after out-of-hospital cardiac arrest: Hispanics and Blacks may fare worse than nonHispanic Whites. Resuscitation. 2019;137:29-34. doi:10.1016/j.resuscitation.2019.01.038.

11. Gräsner J-T, Wnent J, Herlitz J, Perkins GD, Lefering R, Tjelmeland I, et al. Survival after out-of-hospital cardiac arrest in Europe - Results of the EuReCa TWO study. Resuscitation. 2020;148:218-26. doi:10.1016/j.resuscitation.2019.12.042.

12. Metelmann B, Metelmann C, Schneider L, Vollmer M, Fischer M, Bohn A, et al. Anstieg der Laienreanimationsrate in Deutschland geht mit vermehrter Telefonreanimation einher. Notarzt. 2019;35:323-8. doi:10.1055/a-1039-3693.

13. Özbilgin Ş, Akan M, Hancı V, Aygün C, Kuvaki B. Evaluation of Public Awareness, Knowledge and Attitudes about Cardiopulmonary Resuscitation: Report of İzmir. Turk J Anaesthesiol Reanim. 2015;43:396-405. doi:10.5152/TJAR.2015.61587. 
14. Brinkrolf P, Bohn A, Lukas R-P, Heyse M, Dierschke T, van Aken HK, Hahnenkamp K. Senior citizens as rescuers: Is reduced knowledge the reason for omitted lay-resuscitation-attempts? Results from a representative survey with 2004 interviews. PLoS One. 2017;12:e0178938.

doi:10.1371/journal.pone.0178938.

15. Chen M, Wang Y, Li X, Hou L, Wang Y, Liu J, Han F. Public Knowledge and Attitudes towards Bystander Cardiopulmonary Resuscitation in China. Biomed Res Int. 2017;2017:3250485. doi:10.1155/2017/3250485.

16. Paglino M, Contri E, Baggiani M, Tonani M, Costantini G, Bonomo MC, Baldi E. A video-based training to effectively teach CPR with long-term retention: The ScuolaSalvaVita.it ("SchoolSavesLives.it") project. Intern Emerg Med 2018. doi:10.1007/s11739-018-1946-3.

17. Plant N, Taylor K. How best to teach CPR to schoolchildren: A systematic review. Resuscitation. 2013;84:415-21. doi:10.1016/j.resuscitation.2012.12.008.

18. Blewer AL, Putt ME, Becker LB, Riegel BJ, Li J, Leary M, et al. Video-Only Cardiopulmonary Resuscitation Education for High-Risk Families Before Hospital Discharge: A Multicenter Pragmatic Trial. Circ Cardiovasc Qual Outcomes. 2016;9:740-8. doi:10.1161/CIRCOUTCOMES.116.002493.

19. Del Rios M, Morales G, Han J, Campbell T, Sharp L, Gerber B. Major League Soccer Provides a Captive Audience for Promoting Bystander CPR and AED Use Among Hispanics. J Natl Med Assoc. 2018;110:326-9. doi:10.1016/j.jnma.2017.06.014.

20. Greif R, Lockey AS, Conaghan P, Lippert A, Vries W de, Monsieurs KG. European Resuscitation Council Guidelines for Resuscitation 2015: Section 10. Education and implementation of resuscitation. Resuscitation. 2015;95:288-301. doi:10.1016/j.resuscitation.2015.07.032.

21. Rumsfeld JS, Brooks SC, Aufderheide TP, Leary M, Bradley SM, Nkonde-Price C, et al. Use of Mobile Devices, Social Media, and Crowdsourcing as Digital Strategies to Improve Emergency Cardiovascular Care: A Scientific Statement From the American Heart Association. Circulation. 2016;134:e87-e108. doi:10.1161/CIR.0000000000000428.

22. Cheskes S. High School CPR training: It's only an APP away!! Resuscitation. 2017;120:A9-A10. doi:10.1016/j.resuscitation.2017.08.241.

23. Yeung J, Kovic I, Vidacic M, Skilton E, Higgins D, Melody T, Lockey A. The school Lifesavers study-A randomised controlled trial comparing the impact of Lifesaver only, face-to-face training only, and Lifesaver with face-to-face training on CPR knowledge, skills and attitudes in UK school children. Resuscitation. 2017;120:138-45. doi:10.1016/j.resuscitation.2017.08.010.

24. Ahn C, Cho Y, Oh J, Song Y, Lim TH, Kang H, Lee J. Evaluation of Smartphone Applications for Cardiopulmonary Resuscitation Training in South Korea. Biomed Res Int. 2016;2016:6418710. doi:10.1155/2016/6418710.

25. Starks MA, Schmicker RH, Peterson ED, May S, Buick JE, Kudenchuk PJ, et al. Association of Neighborhood Demographics With Out-of-Hospital Cardiac Arrest Treatment and Outcomes: Where You Live May Matter. JAMA Cardiol. 2017;2:1110-8. doi:10.1001/jamacardio.2017.2671.

26. Sakai T, Kitamura T, Nishiyama C, Murakami Y, Ando M, Kawamura T, et al. Cardiopulmonary resuscitation support application on a smartphone - randomized controlled trial. Circ J. 2015;79:1052- 
7. doi:10.1253/circj.CJ-14-1258.

27. Kalz M, Lenssen N, Felzen M, Rossaint R, Tabuenca B, Specht M, Skorning M. Smartphone apps for cardiopulmonary resuscitation training and real incident support: A mixed-methods evaluation study. J Med Internet Res. 2014;16:e89. doi:10.2196/jmir.2951.

28. Metelmann B, Metelmann C, Schuffert L, Hahnenkamp K, Brinkrolf P. Medical Correctness and User Friendliness of Available Apps for Cardiopulmonary Resuscitation: Systematic Search Combined With Guideline Adherence and Usability Evaluation. JMIR Mhealth Uhealth. 2018;6:e190. doi:10.2196/mhealth.9651.

29. Perkins GD, Handley AJ, Koster RW, Castrén M, Smyth MA, Olasveengen T, et al. European Resuscitation Council Guidelines for Resuscitation 2015: Section 2. Adult basic life support and automated external defibrillation. Resuscitation. 2015;95:81-99. doi:10.1016/j.resuscitation.2015.07.015.

30. Prensky M. Digital Natives, Digital Immigrants Part 1. On the horizon. 2001;9:1-6. doi:10.1108/10748120110424816.

31. Bomhold CR. Educational use of smart phone technology: A survey of mobile phone application use by undergraduate university students. Program. 2013;47:424-36. doi:10.1108/PROG-01-2013-0003.

32. Doucet L, Lammens R, Hendrickx S, Dewolf P. App-based learning as an alternative for instructors in teaching basic life support to school children: A randomized control trial. Acta Clin Belg. 2018:1-9. doi:10.1080/17843286.2018.1500766.

33. Paal P, Pircher I, Baur T, Gruber E, Strasak AM, Herff H, et al. Mobile phone-assisted basic life support augmented with a metronome. J Emerg Med. 2012;43:472-7. doi:10.1016/j.jemermed.2011.09.011.

34. Zanner R, Wilhelm D, Feussner H, Schneider G. Evaluation of M-AID, a first aid application for mobile phones. Resuscitation. 2007;74:487-94. doi:10.1016/j.resuscitation.2007.02.004.

35. Choa M, Park I, Chung HS, Yoo SK, Shim H, Kim S. The effectiveness of cardiopulmonary resuscitation instruction: Animation versus dispatcher through a cellular phone. Resuscitation. 2008;77:87-94. doi:10.1016/j.resuscitation.2007.10.023.

36. Zhu N, Chen Q, Jiang Z, Liao F, Kou B, Tang H, Zhou M. A meta-analysis of the resuscitative effects of mechanical and manual chest compression in out-of-hospital cardiac arrest patients.

37. Idris AH, Guffey D, Pepe PE, Brown SP, Brooks SC, Callaway CW, et al. Chest compression rates and survival following out-of-hospital cardiac arrest. Crit Care Med. 2015;43:840-8.

doi:10.1097/CCM.0000000000000824.

38. Duval S, Pepe PE, Aufderheide TP, Goodloe JM, Debaty G, Labarère J, et al. Optimal Combination of Compression Rate and Depth During Cardiopulmonary Resuscitation for Functionally Favorable Survival. JAMA Cardiol. 2019;4:900. doi:10.1001/jamacardio.2019.2717.

39. Merchant RM, Abella BS, Abotsi EJ, Smith TM, Long JA, Trudeau ME, et al. Cell phone cardiopulmonary resuscitation: Audio instructions when needed by lay rescuers: a randomized, controlled trial. Ann Emerg Med. 2010;55:538-543.e1. doi:10.1016/j.annemergmed.2010.01.020. 
40. Sondergaard KB, Wissenberg M, Gerds TA, Rajan S, Karlsson L, Kragholm K, et al. Bystander cardiopulmonary resuscitation and long-term outcomes in out-of-hospital cardiac arrest according to location of arrest. Eur Heart J. 2019;40:309-18. doi:10.1093/eurheartj/ehy687.

41. Olasveengen TM, Caen AR de, Mancini ME, Maconochie IK, Aickin R, Atkins DL, et al. 2017 International Consensus on Cardiopulmonary Resuscitation and Emergency Cardiovascular Care Science With Treatment Recommendations Summary. Resuscitation. 2017;121:201-14. doi:10.1016/j.resuscitation.2017.10.021.

42. Lee JS, Jeon WC, Ahn JH, Cho YJ, Jung YS, Kim GW. The effect of a cellular-phone video demonstration to improve the quality of dispatcher-assisted chest compression-only cardiopulmonary resuscitation as compared with audio coaching. Resuscitation. 2011;82:64-8. doi:10.1016/j.resuscitation.2010.09.467.

43. Plata C, Stolz M, Warnecke T, Steinhauser S, Hinkelbein J, Wetsch WA, et al. Using a smartphone application (PocketCPR) to determine CPR quality in a bystander CPR scenario - A manikin trial. Resuscitation. 2019;137:87-93. doi:10.1016/j.resuscitation.2019.01.039.

44. Johnston TC, Clark MJ, Dingle GA, FitzGerald G. Factors influencing Queenslanders' willingness to perform bystander cardiopulmonary resuscitation. Resuscitation. 2003;56:67-75. doi:10.1016/s03009572(02)00277-0.

45. Abelairas-Gómez C, Rodríguez-Núñez A, Casillas-Cabana M, Romo-Pérez V, Barcala-Furelos R. Schoolchildren as life savers: At what age do they become strong enough? Resuscitation. 2014;85:814-9. doi:10.1016/j.resuscitation.2014.03.001.

46. Apptentative Blog. https://www.apptentive.com/blog/2017/06/22/how-many-mobile-apps-areactually-used/. 2017.

47. Leary M, McGovern SK, Chaudhary Z, Patel J, Abella BS, Blewer AL. Comparing bystander response to a sudden cardiac arrest using a virtual reality CPR training mobile app versus a standard CPR training mobile app. Resuscitation. 2019;139:167-73. doi:10.1016/j.resuscitation.2019.04.017.

\section{Figures}




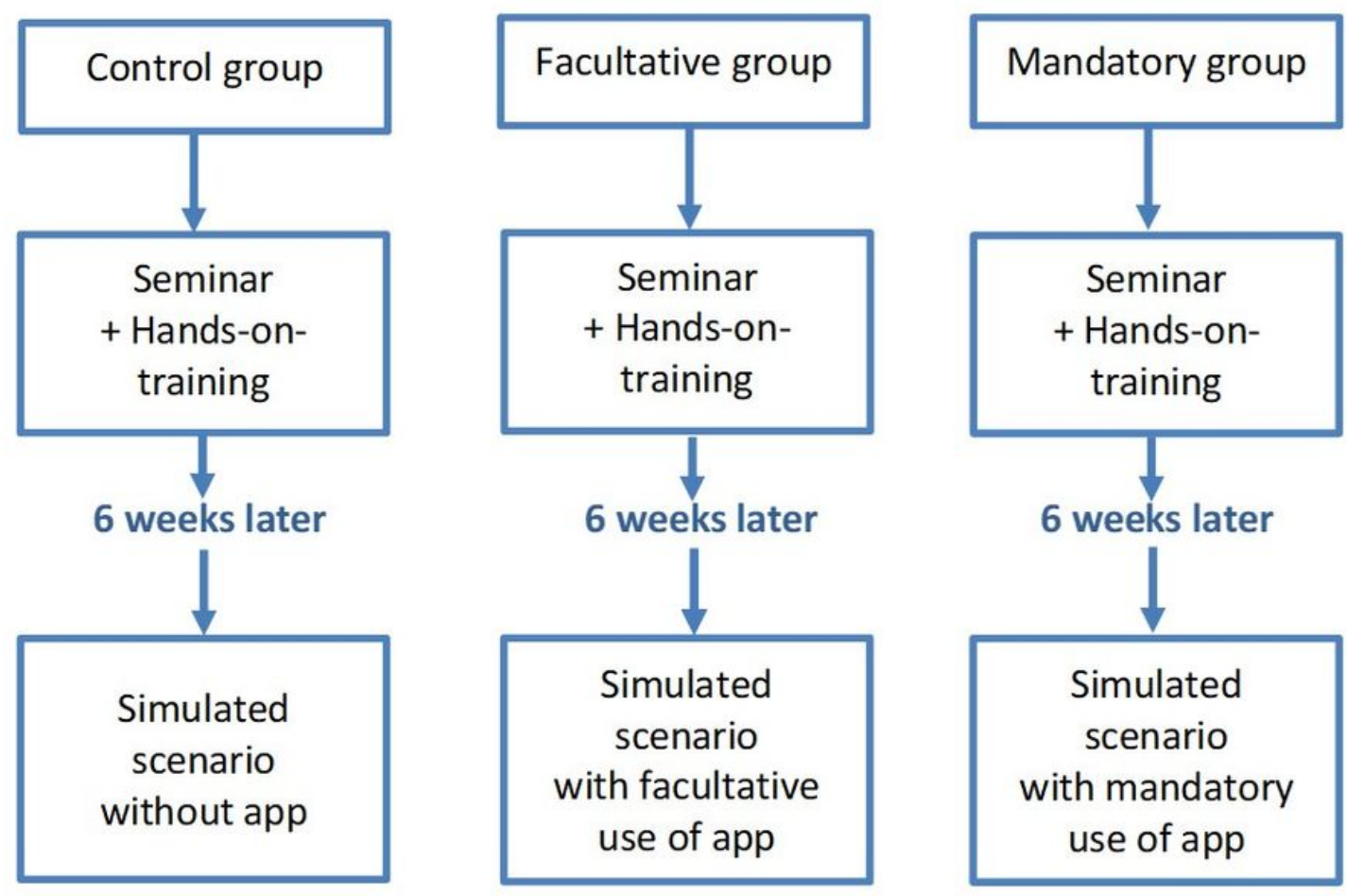

Figure 1

Study design

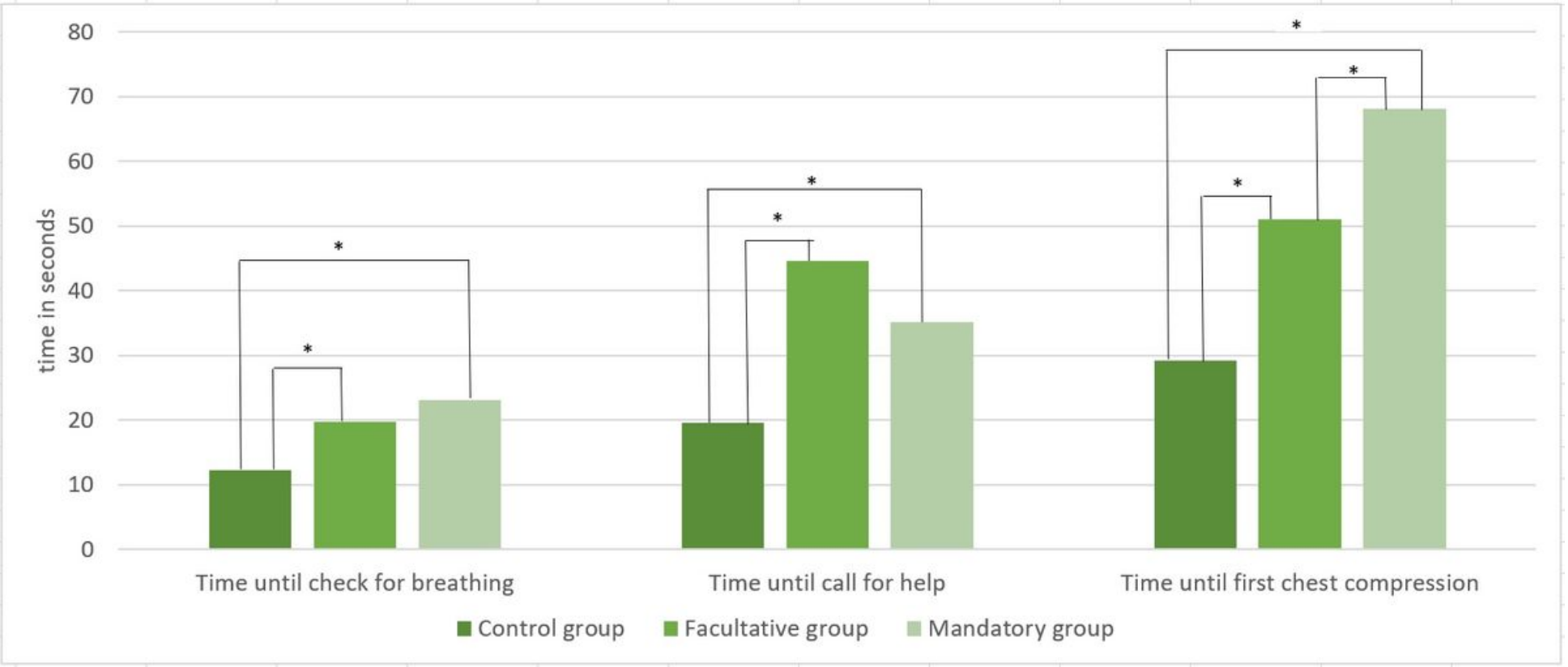

Figure 2

Measured time intervals during simulation (* marks statistical significance with $p<0.001$ ) 
This is a list of supplementary files associated with this preprint. Click to download.

- ESupplementscorechart.pdf

- ETable1.docx 